\title{
Oil and water
}

Tom Cliff

M ost Han in Xinjiang, northwestern China, have settled-or been settled by state decree-in the region since the Chinese Communist Party won the Civil War and took control of China in 1949. Since that time, the proportion of Han in the population has risen from 6 per cent to at least 42 per cent and is now roughly equal to the other major population group in Xinjiang, Turkic Muslim Uyghurs. The massive project of cultural, economic, physical, and personal transformation in which these migrants are involved is rightly described as a 'colonial endeavour?

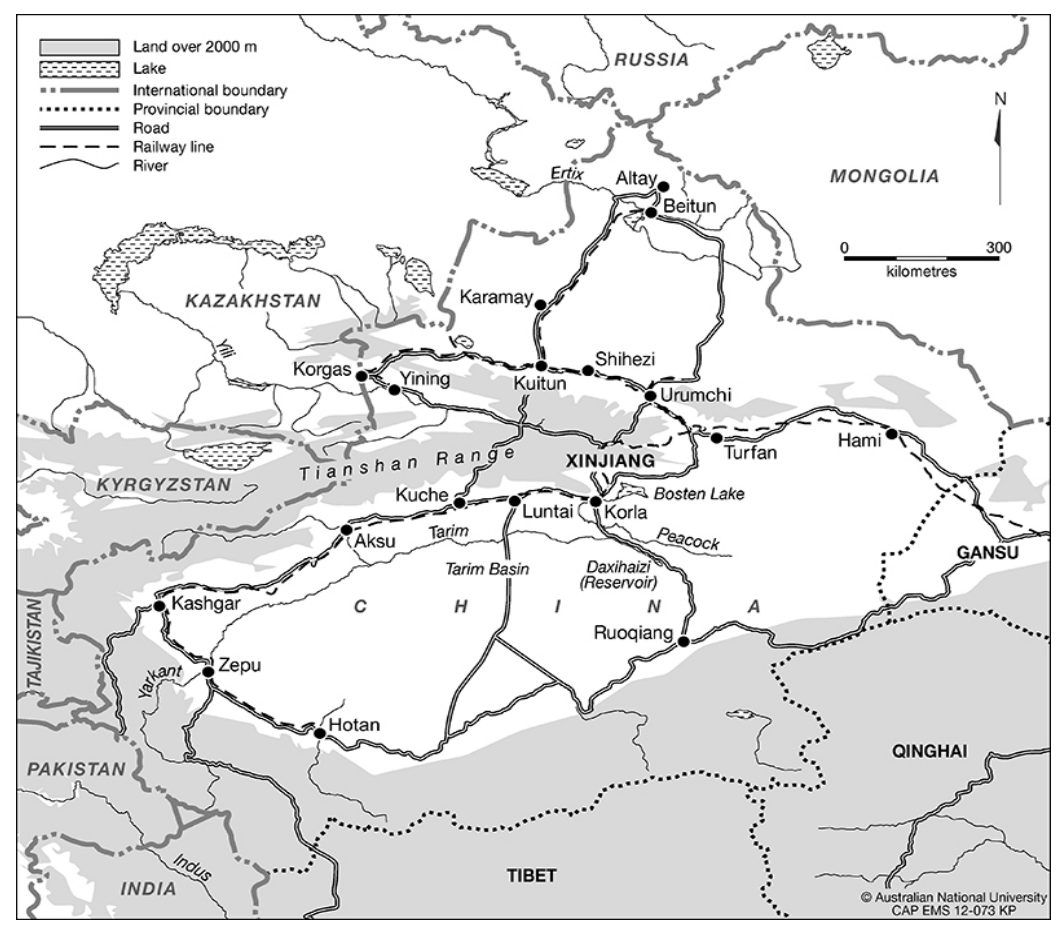

Map 6.I Xinjiang 
Since I first lived in Xinjiang for eight months in 2001-02, I have been asking myself: 'What is it like to be a Han person living in Xinjiang?' I asked myself this question because I felt it was not the same as being a Han person who lives in the core area of China. Perhaps the question came to me because, as an Australian-born child of European parents, I felt some sort of affinity with these settlers on the edge of their empire. Xinjiang was both alien and strangely familiar to me.

I returned to Xinjiang from July 2007 until February 2010 to conduct research on the experiences of Han settlers, centring my project on the oil city of Korla. The resultant book was published in June 2016 by the University of Chicago Press. The following photo gallery contains some highlights from an exhibition held at The Australian National University in early July 2016.

\section{Time}

On 5 July 2009, Ürümqi's streets were witness to some of the worst interethnic communal violence to hit Xinjiang since 1949. Angry and frustrated Uyghurs protested, were met with police violence in response, and then rioted. They burned buildings and vehicles, and randomly beat any Han person unlucky enough to be in their path. Thousands of Han retaliated two days later, destroying Uyghur property and beating-often to death-any Uyghur witless enough to be present on the deliberately lawless streets.

A massive crackdown from the embarrassed and embattled Xinjiang authorities was imminent, violence past and violence-to-be hung heavily in the thick summer air, and fear and loathing were visible on the eerily quiet streets of Xinjiang's cities. The only thing in Xinjiang that was not at least semiparalysed was rumour, which spread like wildfire.

The period from July 2009 to February 2010 was a crucible of politicised storytelling, fired by heightened emotions and unconstrained by the mannered niceties of peacetime. A certain kind of talk became briefly allowable as the assumptions of settler loyalty to Xinjiang and the precepts of Han occupation of the region lost their hold on public discourse. The uncertain months following 5 July 2009 can be seen as a 'decisive moment' in Xinjiang's recent history. 


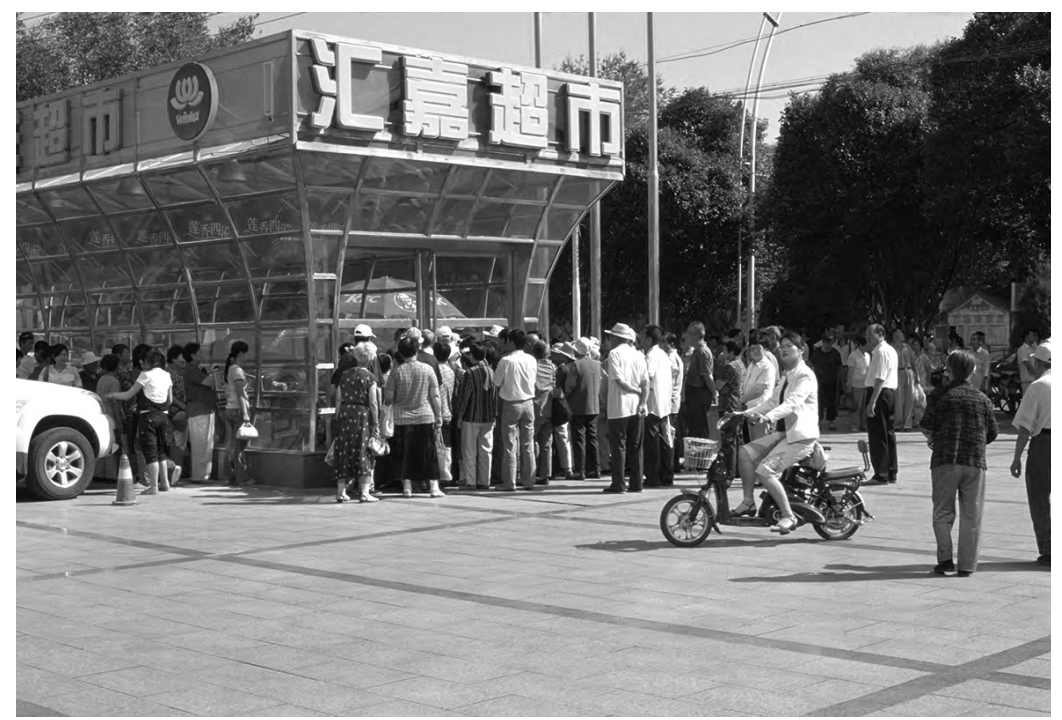

Plate 6.I Friday morning, I0 July 2009. The supermarkets in Korla open for the first time since the Uyghur riots on 5-6 July and Han retribution riots on 7 July. Despite repeated official warnings to avoid crowded public places, all these people seem to want (aside from food supplies) is the comforting, familiar feeling of a supermarket crush.

\section{Migration}

Migration and colonial settlement are core elements of the experience of being Han in Xinjiang. Most Han in Korla are migrants within a generation or two who came to the region in a series of waves since 1949. The first major wave of Han in-migration to Xinjiang began in the 1950s; it was state-sponsored and directed towards a quasi-military agricultural colony called the Xinjiang Production and Construction Corps (兵团, or Bingtuan). The second major wave began in the early 1990s and continues; it is economically motivated and self-sponsored migration, but shaped and strongly encouraged by state actors. The second wave brought Han settlers into more direct contact with Uyghurs in Xinjiang, partly because of a much stronger emphasis on migration into Uyghur-majority areas of southern Xinjiang.

The very act of migration into the 'behindness' that is Xinjiang infects the Han migrant with behindness, although at the same time, the movement often helps to raise their relative social status. Military officers and bureaucratic cadres posted to Xinjiang during the early Mao era (1950s) 
were typically promoted one level; self-sponsored farmer-settlers today are often granted land packages that provide an income far greater than what they could earn in rural eastern China.

Civilians and bureaucrats are the frontline soldiers of the colonial endeavour, yet by becoming 'Xinjiang people'-settlers, not just sojournersthey distance themselves from the cultural core and become themselves subject to this civilising project.

\section{Mao-era settlers}

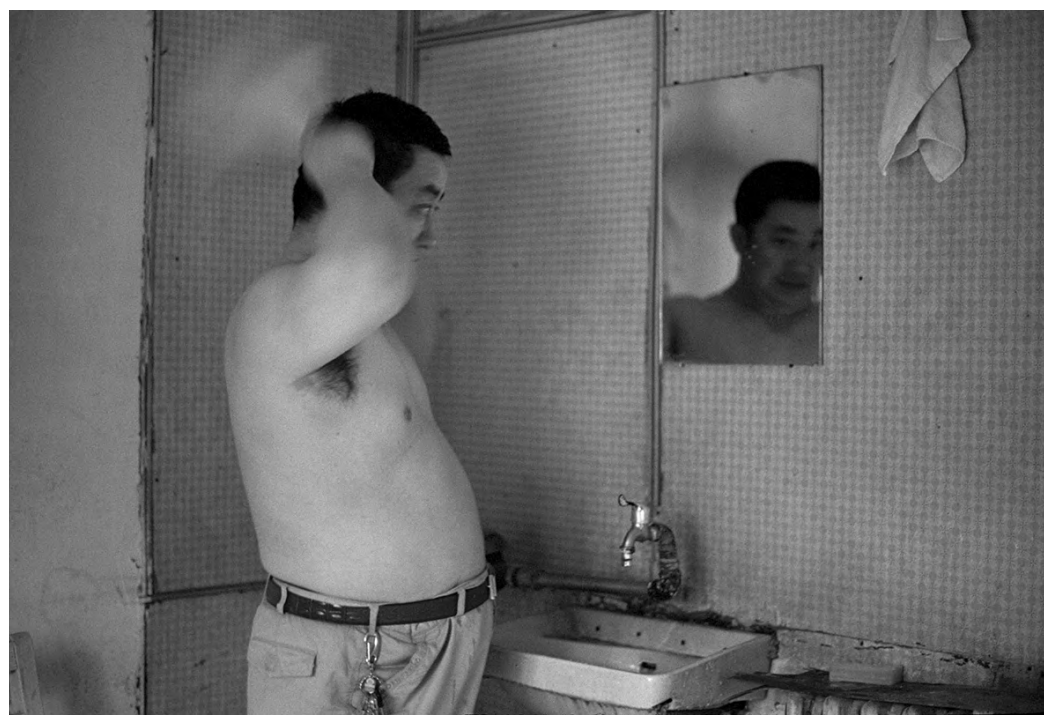

Plate 6.2 Dr Pei in the backroom of his acupuncture and massage clinic, early August 2009. We were having a robust argument about domestic and political violence. Like many Chinese, Dr Pei was offended and angry that the Melbourne International Film Festival was showing a film about exiled Uyghur businesswoman Rebiya Kadeer, and that Australian authorities had refused Chinese demands to drop the film from the festival program and deny Kadeer a visa. The Chinese Government blamed Kadeer for instigating the riot on 5 July 2009, and very few Han people had any cause not to believe that the riots were premeditated and Kadeer was the mastermind. Dr Pei wrung out his towel over and over, occasionally clenching his fist, and insisting that it was absolutely right to govern Uyghurs and women with violence or the threat of violence. 


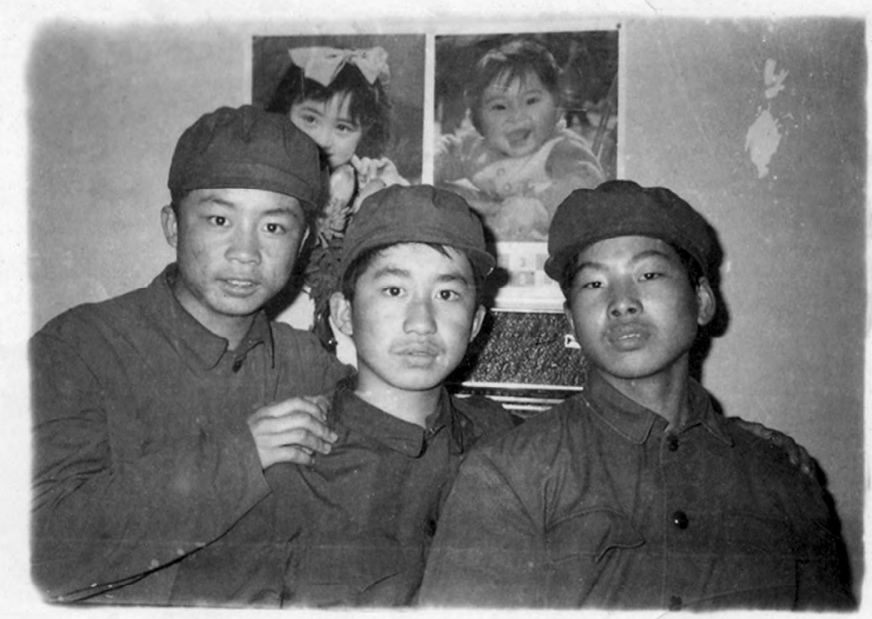

Plate 6.3 Pei Jianjiang (centre) with his two best friends from the transport company school. Mid-1970s.

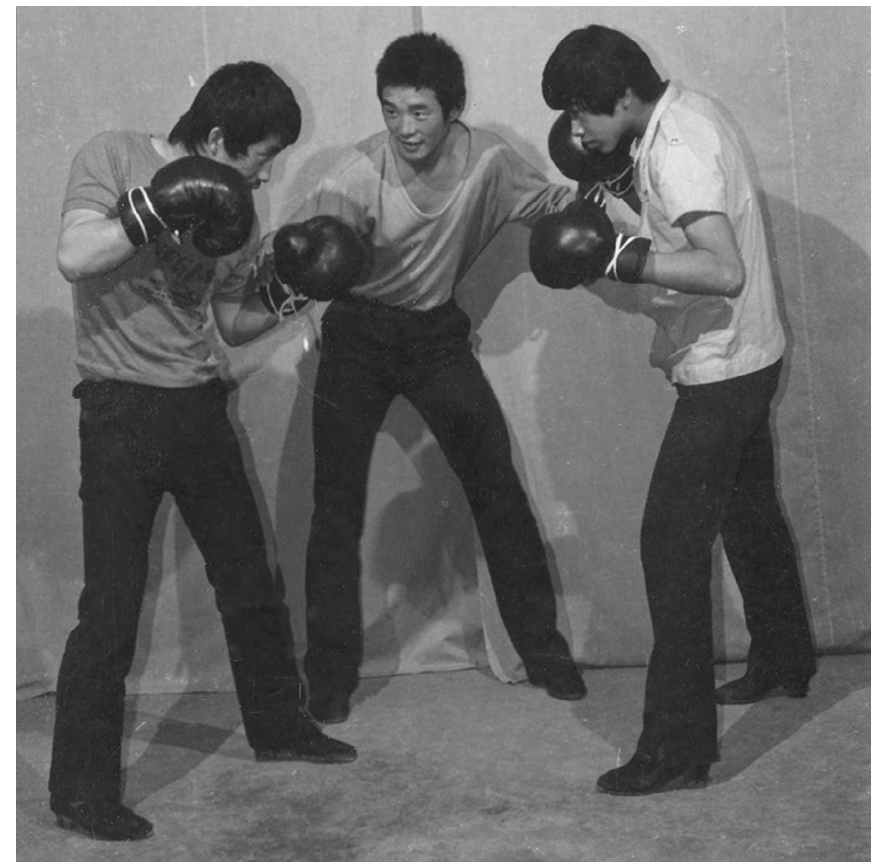

Plate 6.4 Pei jianjiang (left), posing in a local photographic studio with the same two best friends, early 1980s. Soon after this photograph was taken, Pei began studying traditional Chinese medicine and martial arts. 


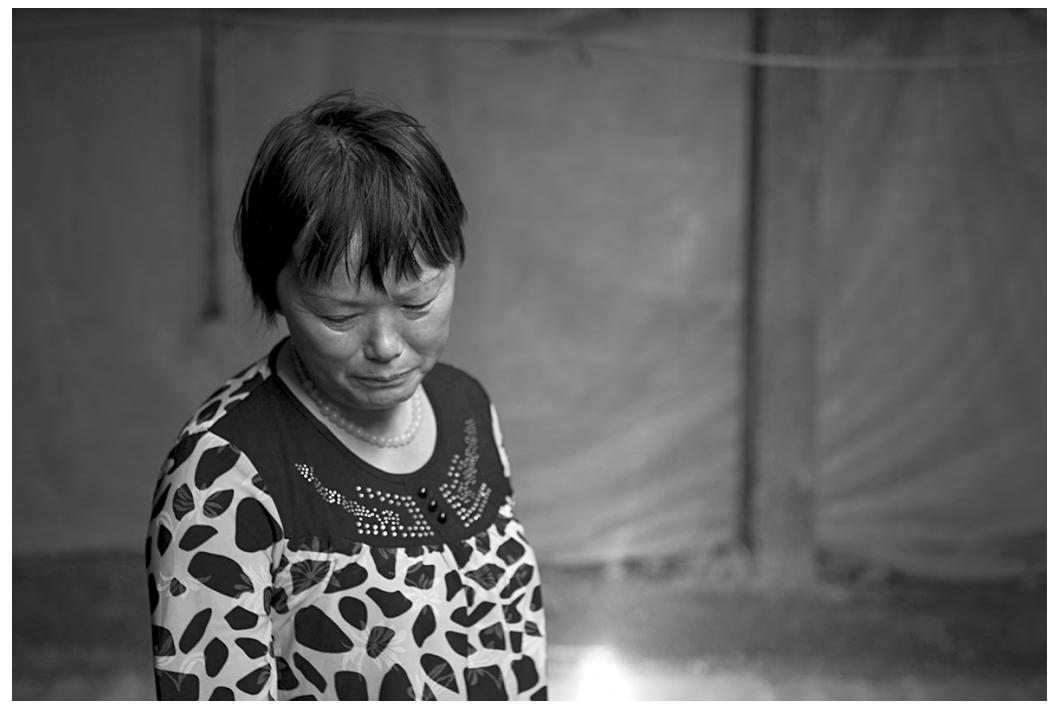

Plate 6.5 Ms Gu at the market garden she runs with her husband. Ms Gu was laid off without a pension from her job as a kindergarten teacher at the 'Third Front' factory, where her husband also worked his whole life.TheThird Front was an industrial policy (1964-80) that relocated urban factories deep inland, supposedly to make them harder to bomb in the event of war. Ms Gu and her husband were relocated from where they lived in eastern China to a remote valley north of Korla. In 2008, Ms Gu was knocked off her bicycle by a passing motorcyclist, sustaining head injuries and suffering memory loss and mild brain damage. The effects of the accident put a strain on her relationship with her husband. 


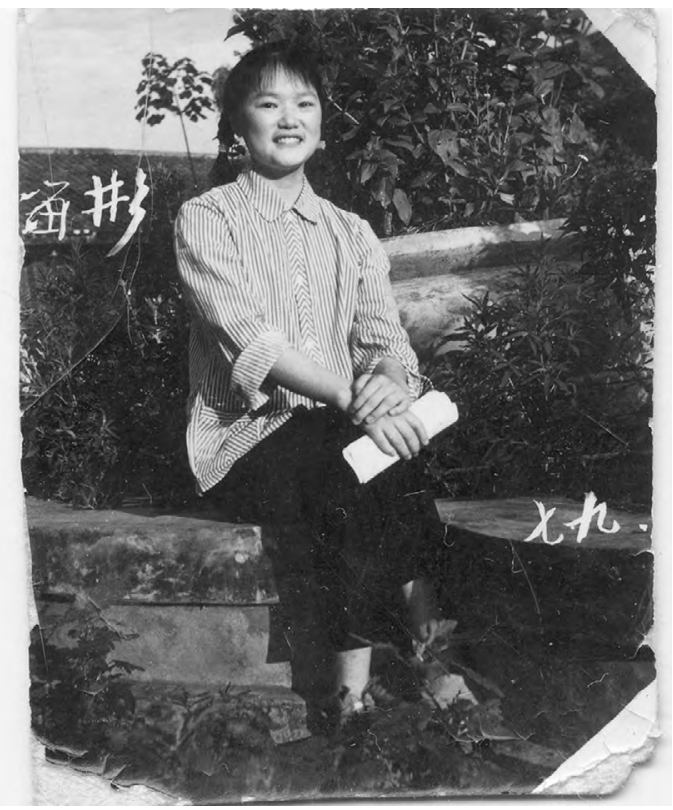

Plate 6.6 Ms Gu at the factory in the mountains, 1979.

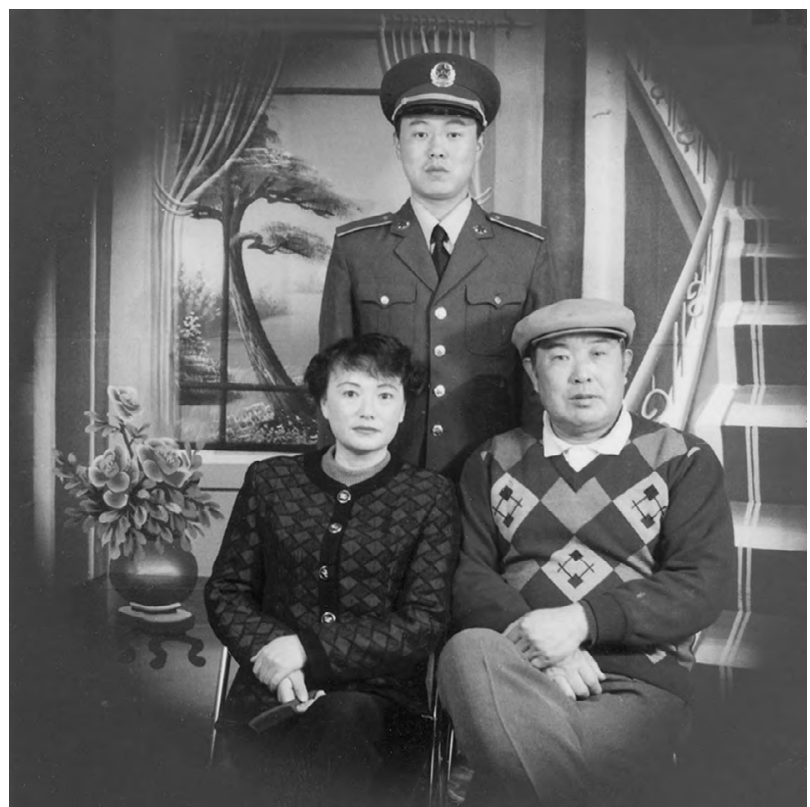

Plate 6.7 Ms Gu with her husband and son, ca. 2005. 


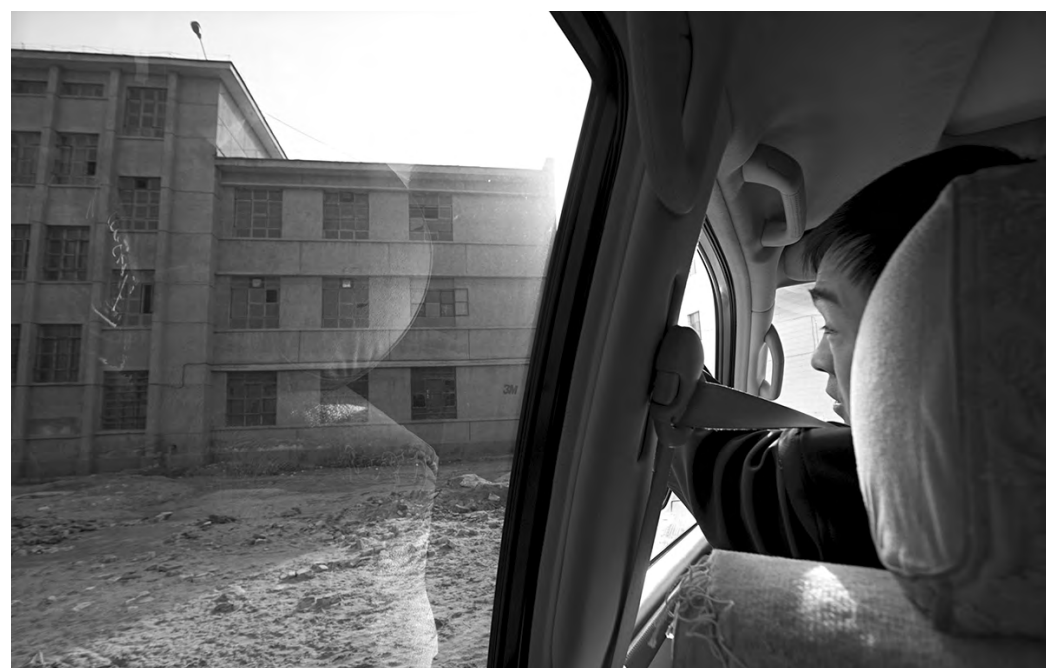

Plate 6.8 Mr Jia in his oil company Land Cruiser in January 2010, looking at the Bingtuan high school from which he graduated in the early 1980s. According to him, at that time, Bingtuan children's greatest wish was to get into university - to shake off the Bingtuan, because life on the Bingtuan was very hard: 'At the same time, [non-Bingtuan] people looked down on you and discriminated against you. So, we studied hard; it was the only way out.'

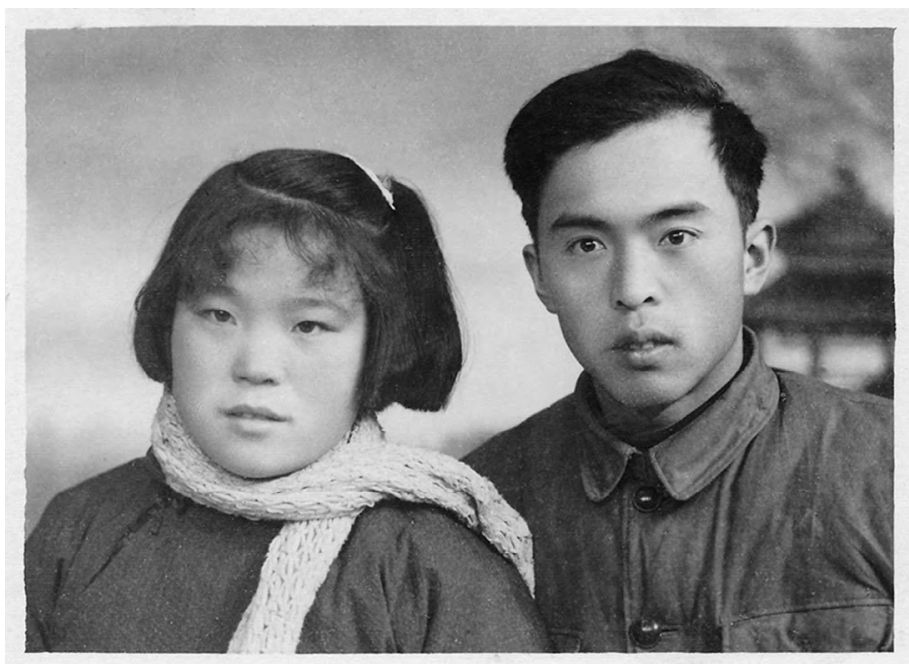

Plate 6.9 Mr Jia's parents after arriving in Xinjiang for his father to take up a company commander position in the Bingtuan, 1963. The Bingtuan was set up as a military-agricultural colony in the early 1950s. Demobilised soldiers of both the Communists and their civil war enemies, the Nationalists, settled marginal arid lands, building extensive irrigation networks with hand tools and sheer force of numbers. 


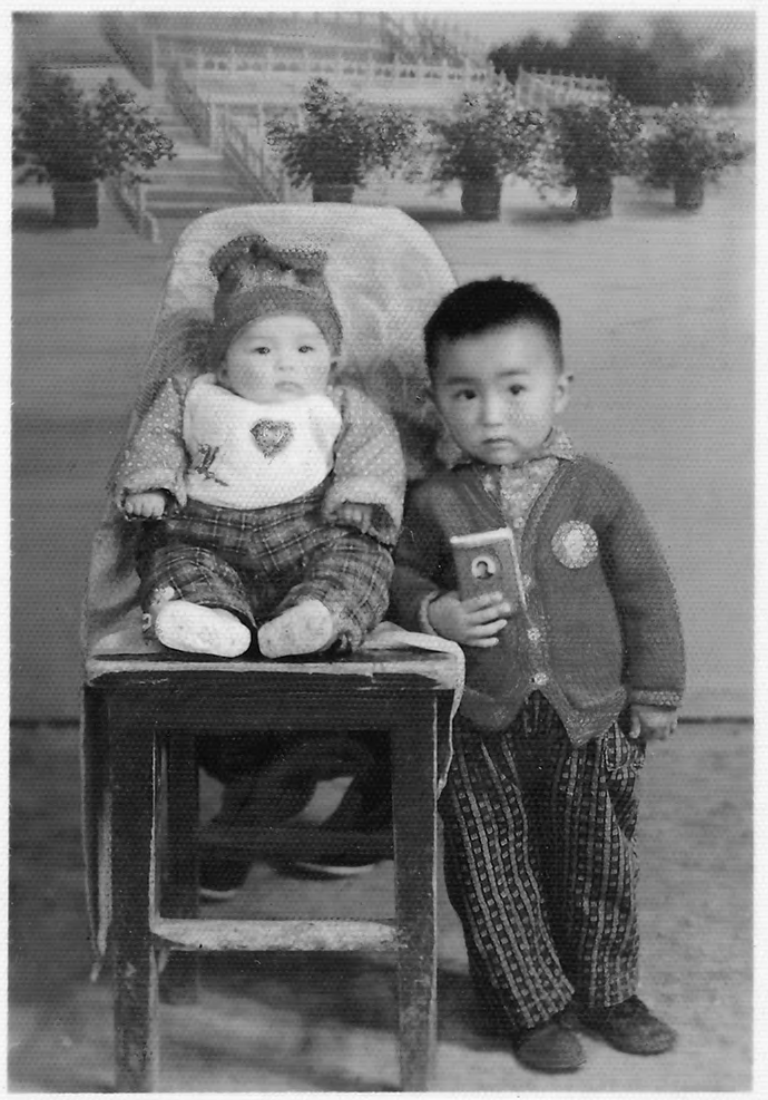

\section{今海文革}

Plate 6.10 Mr Jia, aged four, and his younger sister. He holds Mao's Little Red Book. It is 1969 , a few years into the Cultural Revolution. The original photo was hand-coloured by the studio. 


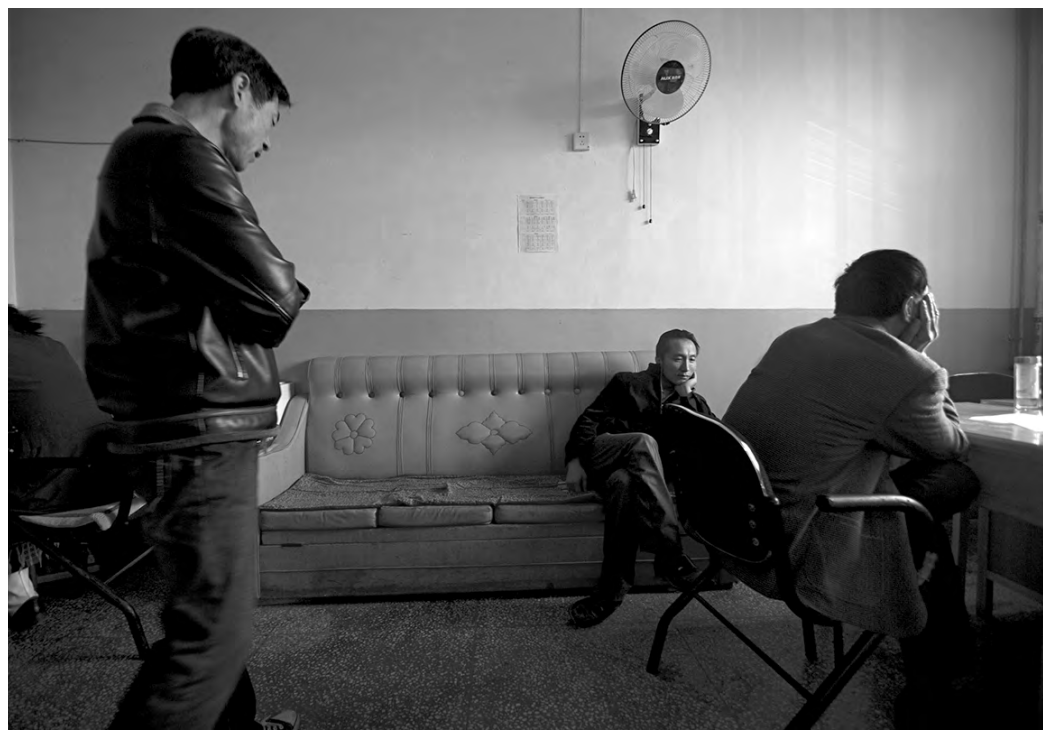

Plate 6.I I Teachers awaiting a negotiation. It is Friday morning and some teachers are sitting in the often-absent principal's office. They have just heard that their working conditions-hours, shifts, responsibilities, calculation of salary, and so on-have once again been changed by their boss, the investor. One month they may have to work or be on-call at the small private boarding school all day every second day; the next month it is back to 12 hours a day, six days a week. They do not like it, but teachers are common, and many new ones are produced every year. These older teachers have little chance of permanent employment in a government school; if they did, they would not be here. They wait and prepare themselves for yet another asymmetrical negotiation. 


\section{Recent settlers}

The Bingtuan began as a system of military-agricultural colonies and was the main force behind Han in-migration to and the cultural transformation of Xinjiang until at least the end of the Mao era. Today, the Bingtuan is almost entirely civilian, but it is still seen by the central government as playing an important role in maintaining social and political stability in Xinjiang-largely because the Bingtuan's population, 94 per cent of whom are Han, occupies key peri-urban, rural, and border regions. Moreover, the legal parameters governing this settler population remain different to those that govern non-Bingtuan populations throughout the rest of rural China, including Xinjiang. These differential modes of governance result in a significant socioeconomic and politico-legal divide between the Bingtuan population (especially the newcomers) and the non-Bingtuan population.

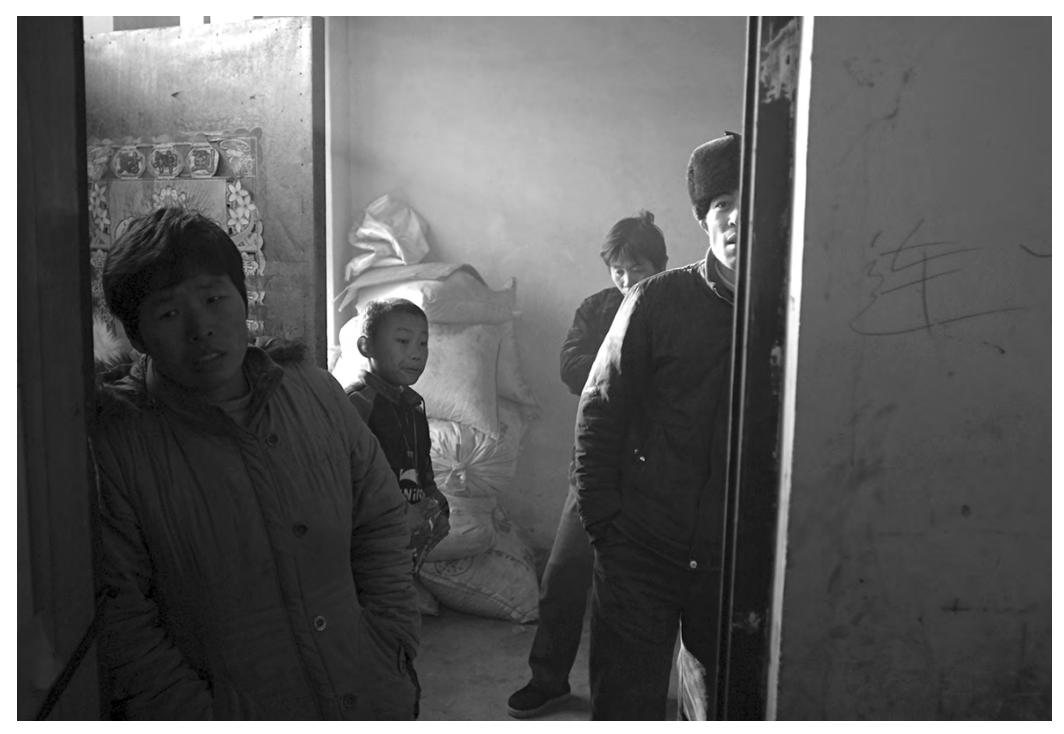

Plate 6. I Exploited tenant farmers on the Bingtuan. 


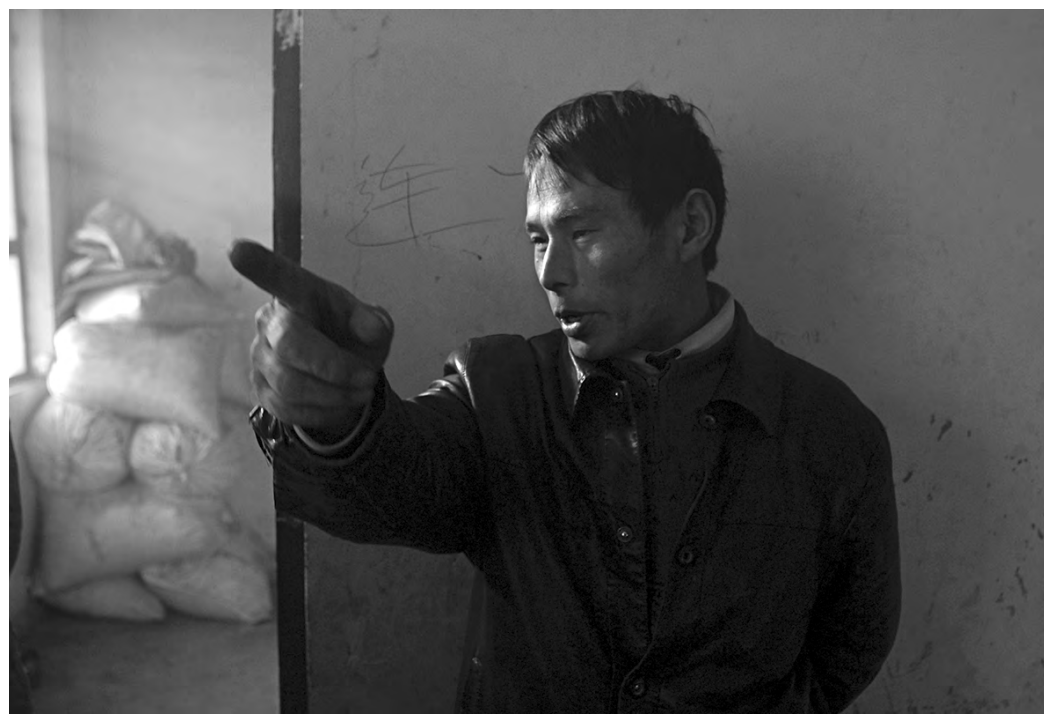

Plate 6.13 Another exploited tenant farmer on the Bingtuan.

Plates 6.12 and 6.13 depict tenant farmers on the Bingtuan, in winter 2007. Their village in inland China was hit by a natural disaster a few years previously, so they opted to come to Xinjiang to start a new life. The conditions of their employment on the Bingtuan as told to them before they came were apparently vastly different to the reality of how they are treated: 'What we have is not even enough to support a family and send a kid to school.'

They were promised 600 yuan a month as a minimum, whether they worked or not, but this has not been paid. Instead, they receive 15 yuan per day, but there is always work arranged for them by the Bingtuan authorities, so 'days off' do not really exist. Their house was apparently to be given to them, but after five years they are expected to pay 'over 10,000 yuan' and if they do not they will be taxed five years of rent for their house. The house is bare, clammy, unheated, unpainted, and small to boot. The man told me the table and wardrobe-both made from cheap plywood and not in good condition-cost 3,000 yuan of their pay and were a mandatory purchase. In this way, the Bingtuan authorities justify holding back their pay. They have 2.6 hectares and must invest 10,000 yuan in agricultural inputs each year. The poor land they work is more costly than that on which earlier arrivals work because the tax rate is fixed at the beginning of the land contract with the Bingtuan. 
The disparity between their income and their needs for investment means they owe money to creditors in their old home in Henan.

Their household registration, which gives them access to basic health care and allows their child to attend school, has been transferred to the village in Xinjiang where they now live. If they returned to their old home, they would effectively be 'non-citizens', because they would not have these rights. Despite this, two-thirds of the people they originally came with have fled the Bingtuan.

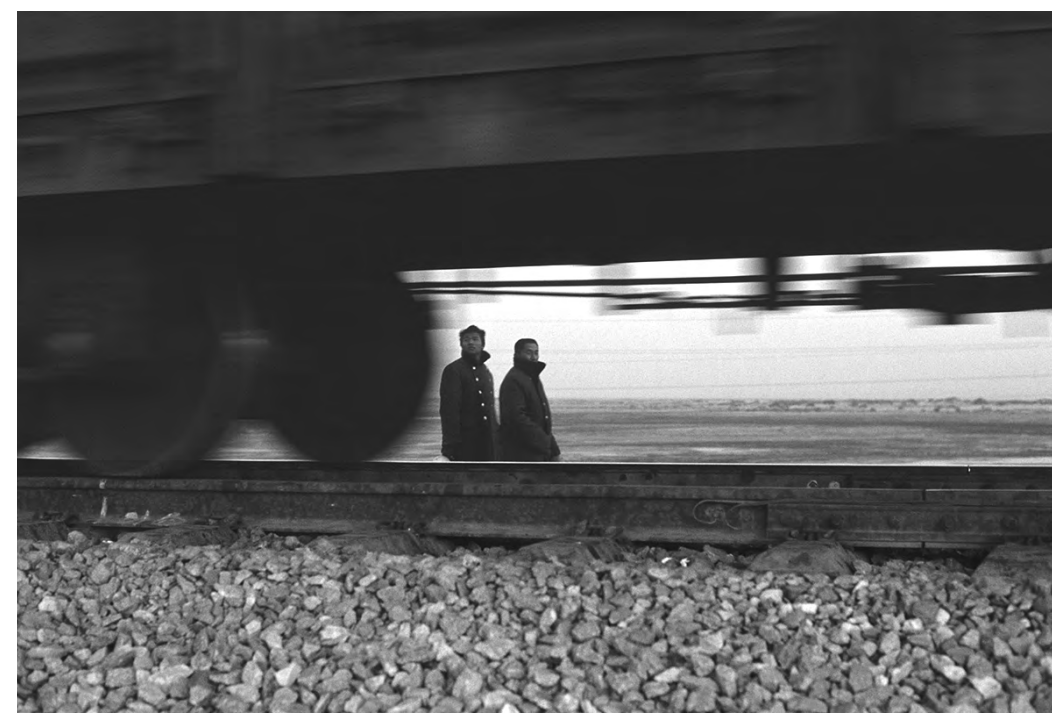

Plate 6. I 4 Train series. Migrant track workers returning home after a day's work. North of Korla, October 2009. 
90 XINIIANG YEAR ZERO

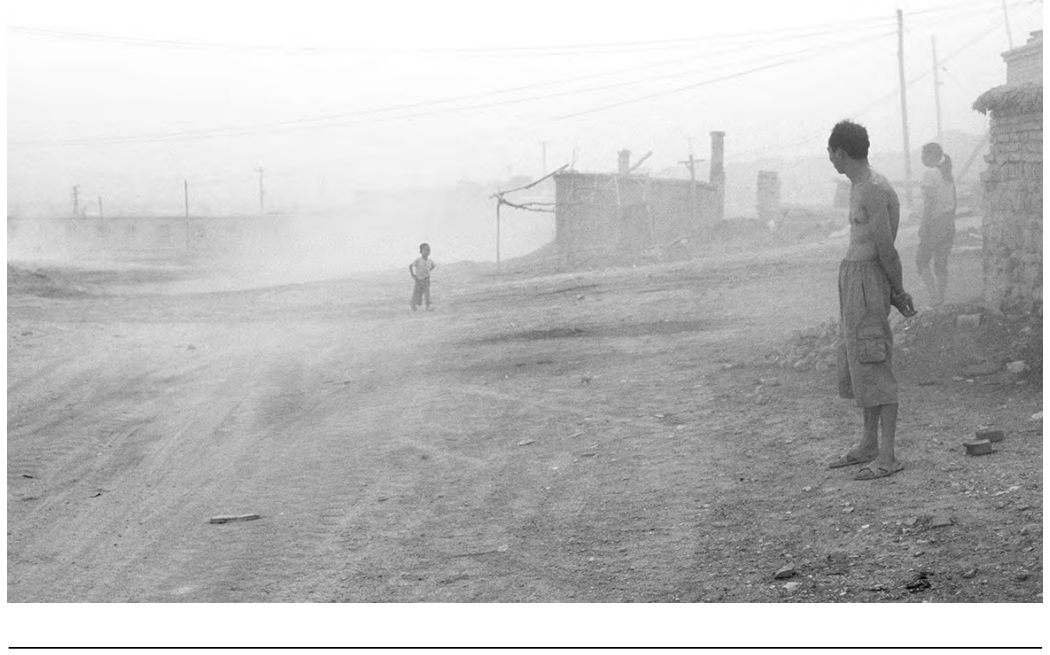

Plate 6. 15 Han on the squatter periphery of Korla, July 2009. 


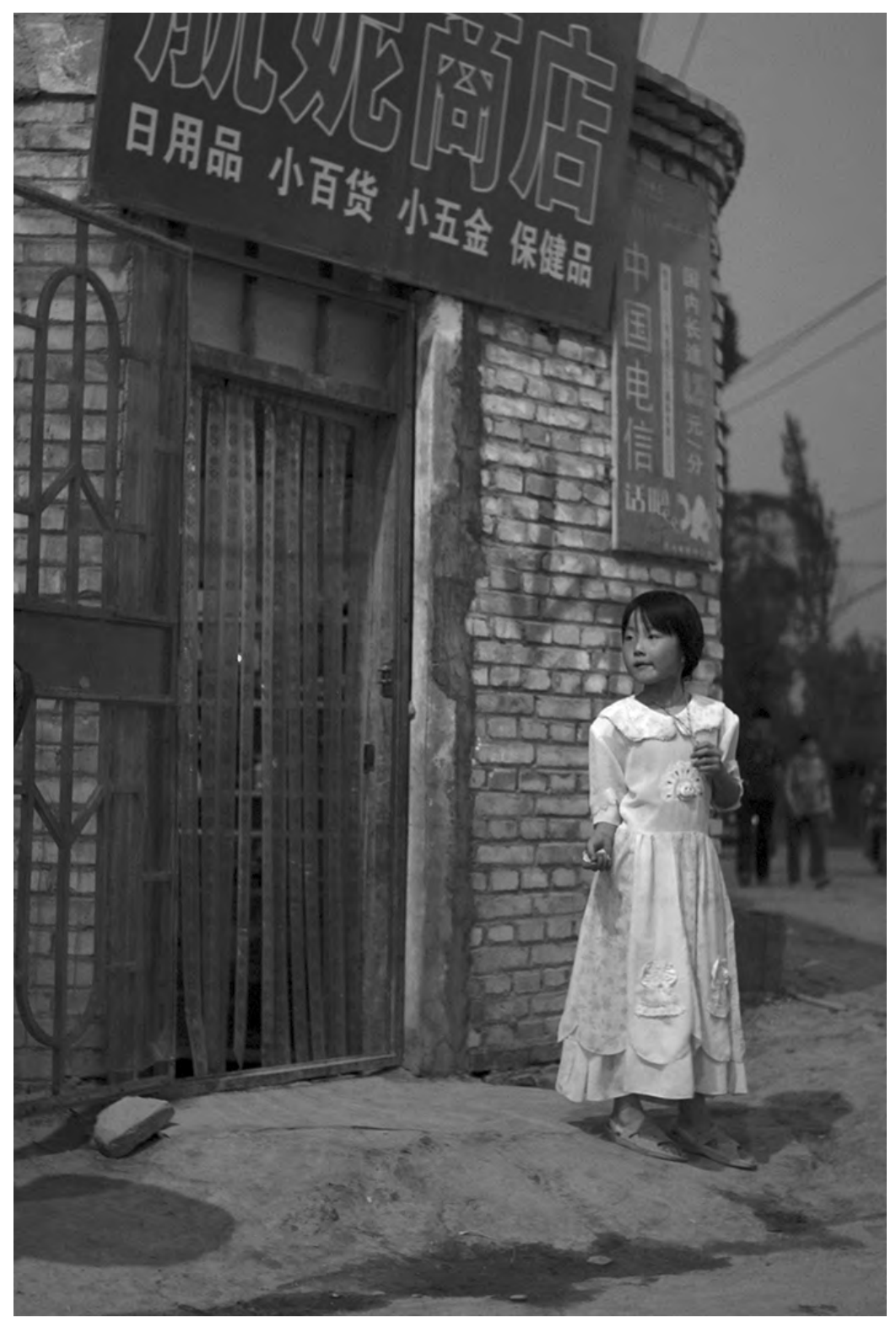

Plate 6.16 A due-for-demolition corner of old Korla, May 2008. 


\section{Empire}

Water and oil are the liquid foundations of empires past and present. Karl Wittfogel famously coined the term 'hydraulic empires' in reference to the 'feudal' formations in which the centre commanded the coercive power to mobilise the population, through corvée or slave labour, to build extensive networks of transportation canals and irrigation channels. Control over water, in a rather different sense, was also the basis of expansionist European colonial empires from the Spanish and Portuguese to the British. These empires relied on their naval prowess-exporting their early modern technologies of power (bureaucracy, culture, and gunpowder-based armaments) into a spatial context in which these technologies conferred an insuperable advantage over the 'natives'. In Xinjiang, the Bingtuan established the irrigation that became the basis on which extensive Han settlement beyond the oases could be sustained-thus transforming, throughout most of the region, the frontier of control into a frontier of settlement.

Water remains important, but oil now flows through the channels of the imperial landscape. Many wars and invasive manoeuvres of the recent past have been motivated by the desire for oil. Oil also fuels and lubricates the global economy and supports and maintains the global status quo. Oil pipelines trace the linkages between political blocs, simultaneously blurring and affirming their boundaries and loyalties. Xinjiang is both an oil and gas-producing base and an essential transit point for hydrocarbons extracted in Central Asia and consumed in China's eastern metropolises. Despite being a domestic company, China National Petroleum Corporation (CNPC) is increasingly involved in offshore investment and oilfield development, as well as being the majority player within the PRC. CNPC is the parent of the Tarim Oilfield Company. The trope of 'oil and water' thus references the liquids that motivate and enable Han activities in Xinjiang, the oil company and the Bingtuan (as the formal institutions most closely associated with these respective liquids), and, more generally, the resources that have played and continue to play the key roles in the expansion and maintenance of imperial formations. Last but certainly not least, 'oil and water' metaphorically express the diverse experiences of Han people in Xinjiang. 


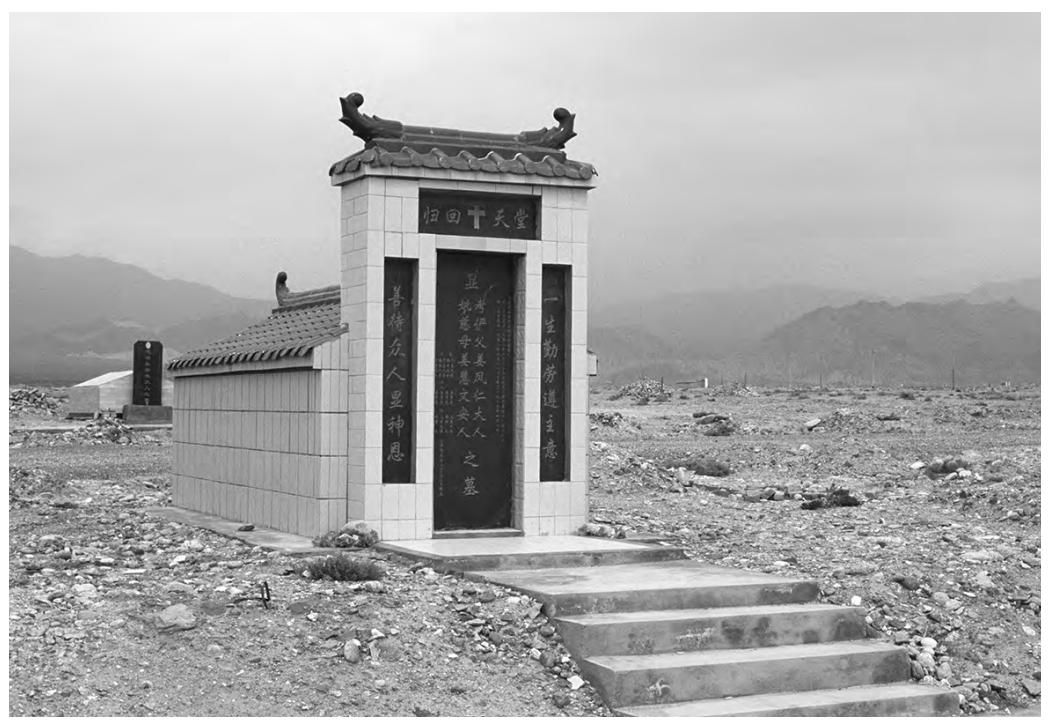

Plate 6.17 Mausoleum in a Mongol autonomous county.

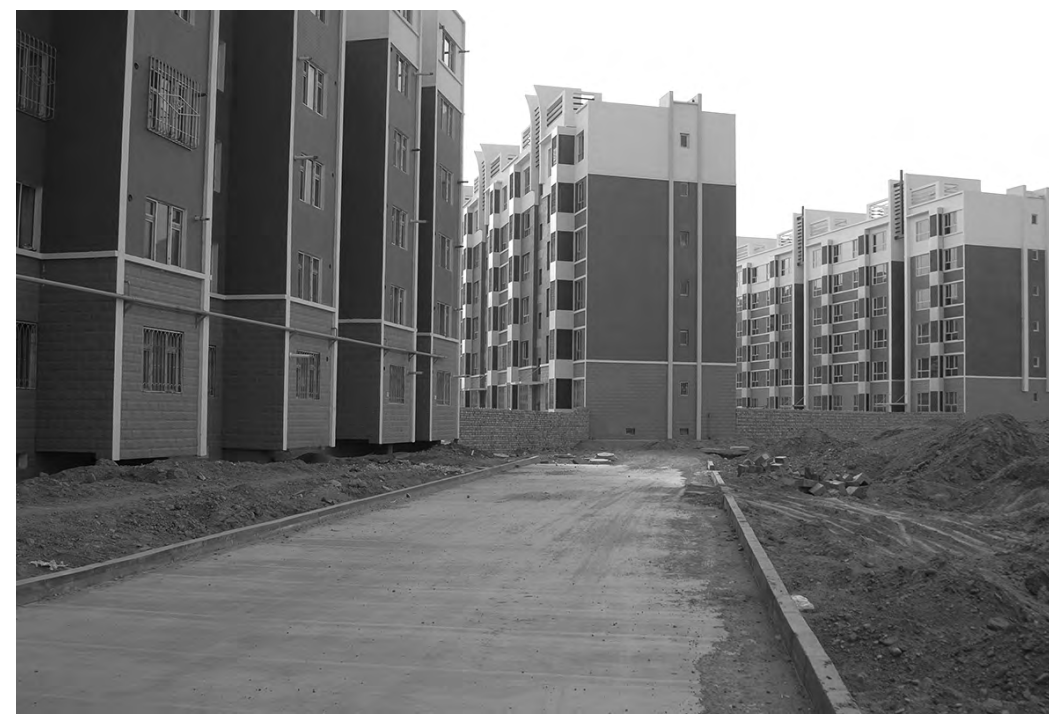

Plate 6.18 Apartment buildings in Korla's New City District. 
94 XINJIANG YEAR ZERO

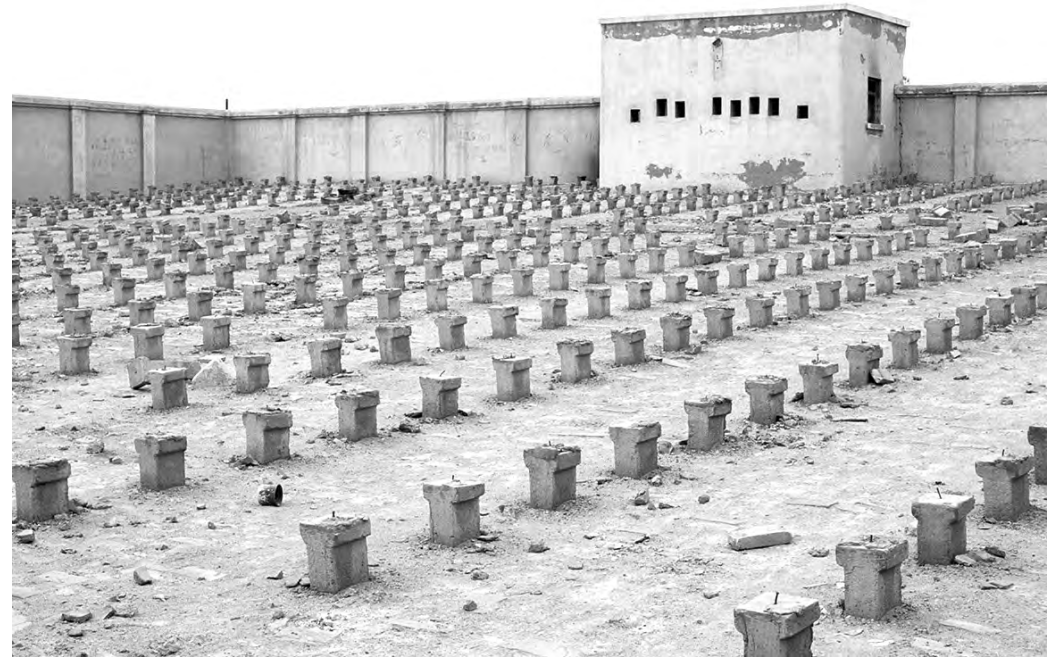

Plate 6.19 Abandoned cinema in a former 'Third Front' factory south of Korla. 
This text is taken from Xinjiang Year Zero, edited by Darren Byler, Ivan Franceschini and Nicholas Loubere, published 2022, The Australian National University, Canberra, Australia.

doi.org/10.22459/XYZ.2021.06 